\title{
HISTORY AND STRATEGY
}


PRINCETON STUDIES IN

INTERNATIONAL HISTORY AND POLITICS

Series Editors

John Lewis Gaddis

Jack L. Snyder

Richard H. Ullman 


\title{
HISTORY AND STRATEGY
}

\author{
Marc Trachtenberg
}


Copyright (C) 1991 by Princeton University Press

Published by Princeton University Press, 41 William Street,

Princeton, New Jersey 08540

\section{All Rights Reserved}

Library of Congress Cataloging-in-Publication Data

Trachtenberg, Marc, 1946-

History and strategy / Marc Trachtenberg.

p. $\mathrm{cm}$.- (Princeton studies in international history and politics)

Includes bibliographical references and index.

ISBN 0-691-07881-5 (cloth : alk. paper)-ISBN

0-691-02343-3 (pbk. : alk. paper)

1. Strategy. 2. Military history, Modern-20th century.

I. Title. II. Series.

U163.T73 1991

$355.4^{\prime} 09^{\prime} 04-\mathrm{dc} 20 \quad 90-21036$

This book has been composed in Linotron Sabon

Princeton University Press books are printed on acid-free paper and meet the guidelines for permanence and durability of the Committee on Production Guidelines for Book Longevity of the Council on Library Resources

Printed in the United States of America

$$
\begin{array}{llllllll}
3 & 5 & 7 & 9 & 10 & 8 & 6 & 4
\end{array}
$$

